\title{
The Hidden Victims of Covid-19 Pandemics
}

\author{
Mohammad Shakil Ahmad ${ }^{1}$, Ajay G. Pise ${ }^{2}$ \\ 'College of Medicine, Majmaah University, Saudi Arabia; Email: m.shakil@mu.edu.sa \\ ${ }^{2}$ Dadasaheb Balpande College of Pharmacy, Besa, Nagpur, M.S., India
}

Sci. Journal Impact

Factor: 6.1 (2018)

ICV: 90.90 (2018)

Scopus'

Year 2020 shall always be known to human history for Covid-19 pandemic. The current Covid-19 pandemic has provoked government and local bodies globally to enforce strong measures to save the human race. Appreciable efforts have been made by WHO and individual State Governments to control the corona-virus pandemic. In general, however, governments have broad leeway during time of emergency to exercise temporary authority over typically protected activities. Imposing complete lockdown was one such strategy aiming to identify infected cases and control the spread. Mobility was completely restricted during lockdown leading to economic slowdown of market. This has affected severely to jobs, business and education sector making noticeable damage globally.

We can identify and get a count of the people infected or killed by this virus. We can also calculate and make a tally of jobs layoffs, adverse economic effects, even the students who are at home and switched over to a new way of teaching instead of in regular classroom teaching. We all have adapted the importance of social distancing of 1meter separation, an unwettedincantation of "six feet under," deemed by London officials the felicitous depth for burying a corpse during a 1665 plague outbreak. But the concern here is how do we quantify something as inchoate as hunger or starvation, fear or anguish?

In the last few weeks we have observed sharp rise in confirmed covid-19 cases in some of the world's largest and congested slums.Experts in Public health worry about the number of people harboring infection in developing world is huge than current figures estimated till now. A study in India by a consortium of universities estimated that the country's factual number of covid 19 positive cases could he much higher than 12 times the current official numbers reported till now due their low socio-economic status and their living conditions. But even if the virus doesn't spread in crowded cities and rural areas where effective social distancing is near to impossible, the pandemic has already exacted a bitter price. For millions of people suddenly deprived of livelihoods, daily wages and the means for their families' survival, poverty and hunger may kill sooner than the coronavirus.

It's very disappointing to see that the economy of India is dependent on hard work of laborers and the same laborers are pushed on the verge to perish. The callous attitude of ruling class towards migrant workers, thinking that these people are not required at all now and if need arises they can be recalled. The labor laws in two big states of India namely Uttar Pradesh and Madhya Pradesh are changed overnight to favor big corporates. Change in labor laws doesn't only affect and alter their long working hours but also lack of basic facilities like safe drinking water and canteen facilities. On interviewing some people who have set out for the herculean journey from their place of work to their respective natives which are thousands of kilometers away, it seems they are going through the mental trauma and physical agony because of loss of wages, starvation and loss of their loved ones who lost their lives in midst of perilous journey. Even after traversing the journey on foot for over a week and reaching homes with great difficulty, the ruling class had different plans for them, making their life more miserable by spaying whole bunch of laborers with disinfectant. There are serious questions are being raised on seeing their test results they are holding in their hands, in which only temperature was recorded with no documentation of any test done for covid 19.

The repercussions of the coronavirus pandemic have resulted in the global economy plummeting for the first time since 1990. Reports released by researchers at King's College London and Australian National University provide data supporting that around $8 \%$ of the world population has been pushed into poverty after analyzation of reduction in domiciliary expending.

As the global economy comes to abeyance due to the pandemic, stories of despair are becoming familiar in almost every country but especially in the developing world where social buffers are thin or often missing. Stories like that of Nazeer Ahmad, a taxi driver in Mumbai, and a father of three. Over the last three months, as Mumbai's airport is shut down and the tourism virtually nonexistent, his wages are completely dried up, making it impossible to pay his monthly house rent. While his landlord has been understanding, it's unclear how long such patience will last. "This virus will starve us before it makes us sick," Ahmad said. Several Ahmed and Shiva are hidden sufferer of Covid-19 pandemic. 
The report on measure of economic consumption noted sharp decline in household income by $5 \%$ to $20 \%$ in different countries, more so in developing world. Even the least decline in present situation of $5 \%$ in developing countries like India would see income-based poverty increase to a greater extent. As per several reports it is expected that, the number of people living in poverty would increase by $1 \%$ to $2 \%$, to between 85 million to 135 million people across the developing world.

The report looked at what would happen if economic consumption measured as either a decline in household income or household spending in a given country dropped by $5 \%$, $10 \%$ or $20 \%$, and how that would impact people in the developing world living in poverty. Even a conservative estimate of a $5 \%$ decline would see income-based poverty increase for the first time in 30 years. At this level, a 10\% drop in consumption would result in an estimated 180 million to 280 million people falling into poverty. And at $20 \%$, some 420 million to 580 million people would be pushed into poverty.

The report delves into the after effects of the pandemic observing the economic consumption evaluated on the basis of reduction of household expenditures in a specific country and the resultant impact on poverty ridden households in developing countries by variation in percentages ranging from $5-20 \%$. Intelligibly, all the nations particularly developed nations like United States and United Kingdom are suffering from the pandemic, the focus remains on stemming the danger facing their own citizens, Sumner said. "I guess, what we're hoping, is to try and open it up a bit. We need to worry about people all over the world, many of whom may not have the coping mechanisms that the rich countries have at their fingertips." 